\title{
Occupational Health And Environment
}

\author{
Salma Ummul, Kameswara Rao K
}

\begin{abstract}
Occupational environment presents potential health hazards to workers employed in a variety of positions. A large number of agents and a diversity of unhealthful work place settings are associated with occupational diseases. In comparison with the larger particles, the invisible particles of diameter 2.5 micro meters (PM 2.5) or smaller have been of greater concern recently. The review study recommends an action plan and a long term strategy to improve the health of the public.
\end{abstract}

\section{Index Terms-Health, Environment, Disease.}

\section{RIVIEW}

The development in the field of Science and Technology has enabled man to make far reaching changes in his natural environment. All human beings are affected in some way by exposure to environment hazards associated with lifestyle at work, at home, during recreation or while travelling in the expressway. Occupational Health often is regarded as a topic that is closely allied with Environment Health and is a subset of broader environment health concerns.

Consideration of health effects are with regard to environmental and temporal factors i.e. Temperature, climate and timing of exposure (3). Among the major determinants of health are the environment, physical, social, personal life style factors, constitution factors such as heredity and human biology and health care dimensions such as access to and quality of medical care and methods for organization of health care systems (4).

Occupational environment presents potential health hazards to workers employed in a variety of positions. The scope of occupational environment is diverse and poses hazards to the workers who are employed in different types of employment settings. A large number of agents and a diversity of unhealthful work place settings are associated with occupational diseases. A disease is defined as those health outcomes that are caused or influenced by exposures to general conditions or specific hazards encountered in the work environment. (5) Occupational illness and injuries are a substantial cause of morbidity and mortality. The agent factor associated with occupational disease and injuries include dust, noise, CO, respiratory diseases, fumes, toxic metals, microbial agents, ionizing radiations, work related stress, and accidents.

Occupational environment presents potential health hazards to workers employed in a variety of positions. Among the potential dangers encountered in the work place are high noise levels, fumes and dusts, toxic chemicals, ionizing and

Salma Ummul, Post Dcotoral Fellow (UGC), Department of Environmental Sciences, Andhra University.Visakhapatnam, Andhra Pradesh, India

Kameswara Rao K, Professor, Department of Environmental Sciences, Andhra University, Visakhapatnam, Andhra Pradesh, India non ionizing radiations, high temperature, bio-hazards and psychological and social hazards including stress.

Emissions from road traffic from both combustion and friction processes, results in complex mixture of air pollution which known to have adverse effects on health (Hoek et al, 2002) .Among other things chemical composition pertains to the soot content (expressed either as black smoke or as elemental carbon and organic carbon. The concentration of PAH's and the concentration of heavy metals such as $\mathrm{Cd}, \mathrm{Cr}$, $\mathrm{Cu}$ and $\mathrm{Zn}, \mathrm{Pb}$ is still problem in many countries because of its continued use in transport fuels.

Particles are classified as $\mathrm{PM}_{10}$ and $\mathrm{PM}_{2.5}$. $\mathrm{PM}_{2.5}$ pollutants include the class of particles that are called ultrafine (diameter of 0.1 to 2.5 micro mts. In comparison with the larger particles, the invisible particles of diameter 2.5 micro meters $\left(\mathrm{PM}_{2.5}\right)$ or smaller have been of greater concern recently. PM 2.5 particles have the capability to bypass the body's natural clearance mechanisms. Particles emitted from vehicular exhausts of more than 10 micron size are held in upper respiratory tract and particles less than 10 microns size (PM 10) accumulates in the lung and produces respiratory abnormalities. Hence $\mathrm{PM}_{10}$ is of great concern in air pollution studies.

Symptoms of air pollution include burning eyes, aching lungs, difficulty breathing wheezing, coughing, head ache and scratching throat or irritate nose $(6,10)$. Health effects associated with air pollution include some forms of cancer such as lung cancer and skin cancer from possible depletion of ozone layer damage to vital tissues and organs such as the nervous systems and impairment of lungs and breathing functions. Prominent problems among people who stay a longer period of time in traffic jam are Mental stress, Headache, Hearing problem, unexpected sweating, Tiredness, Eye problems, breathing problems. Physical problems are suffocation, respiratory problems, heart disease, fever, dust allergy, digestion problem, and dehydration.

The major subgroups of the population that appear to be most sensitive chronic obstructive pulmonary, cardiovascular disease, influenza and asthmatic (8, 9). A Reversible decrement in pulmonary function in population exposed to traffic pollution (7). Among vehicular flow, diesel vehicles are in higher population. Smoke is one of the small size and large number of particles offer greater surface area that allows toxic organic compounds to get absorbed easily. Fine smoke particles can go deep into the lower respiratory tract and damage the lung tissue. Studies have proved that diesel vehicles emit fine and ultra fine particles in very large quantities (2). Most of the particles in diesel exhaust are very fine and capable of being inhaled deeply in the lungs, where they may have a carcinogenic effect. For this reason, lung cancer has been a particular focus of research on the effects of diesel exhaust, which is also thought to contribute to airway inflammation, allergies and asthma.

Aerosol particles also known as particulate matter PM include dust soot and other finely divided solid and liquid materials that are suspended in and move with air particles pollution can 
cause eye, nose throat irritation and other health problems (4). Effects of Smog are eye irritation, irritation of the respiratory tract, chest pains, cough, shortness of breath, nausea and head ache. (3). A few studies suggest an increased (risk of incidence of lung cancer in people with long term exposure to transport related air pollution in cardiovascular morbidity as well a significant increase in risks of myocardial infarction following exposure.

Some studies suggest that it also causes adverse outcomes in pregnancy, such as premature birth and low birth weight but the available evidence is inconsistent. Laboratory studies indicate that transport related air pollution may increase the risk of developing an allergy and can exacerbate symptoms, particularly in susceptible sub groups.

Reducing risks also requires knowledge of significant short term exposure to high level of pollution (which is often experienced in dense traffic) in contrast to risks from long term exposure to low levels which may be experienced by large population. To evaluate adverse health effects administering self report questionnaires, physiologic or clinical examinations are other means to evaluate adverse health effects.

Gardener points out that epidemiological method of investigation are incomplete without good exposure data to parallel information on health. For the successful interpretation of results and implementation of any required preventive programs (8), the need for monitoring environment and biological exposure is paramount. To evaluate adverse health effects administering self report questionnaires, physiologic or clinical examinations are other means to evaluate adverse health effects.

The review study recommends an action plan and a long term strategy to improve the health of the public.

\section{ACKNOWLEDGEMENTS}

The author owes a heartfelt gratitude to Almighty and her Prophet (S.A.W) for giving her health, wealth and strength for carrying out the Post Doctoral Studies at Andhra University. The author is forever indebted to her Parents and Family members.

The author is thankful to her Guide, Professor K Kameswara Rao, for providing a helping hand in every walk of her research, support and guidance extended in pursuing her Post Doctoral Degree.

The author acknowledges all the authors in the References.

\section{REFERENCES}

[1]Balmes J (1993) The role of ozone exposure in the epidemiology of asthma. Environ Health Perspective

[2]Centre of Science and Environment (2004) Astrima : the inside story. Down to Earth. March , 68.

[3]Edwards J, Wakters S, Griffiths R (1994) Hospital admissions for asthma in preschool children

[4] Grandjean P. Epidemiological studies of environmental exposure and specific diseases . Arch Environ Health. 1988;43:69-74

[5]Gochfeld M. Chronologic history of occupational medicine. J Occup Environ Med. 2005;47:96-114

[6]Hoek $\mathrm{G}$ et al. (2002). Association between mortality and indicators of traffic - related air pollution in the Netherlands : a cohort study.Lancet , 360 (9341):1203-1209.

[7] South Coast Air Quality Management District (AQMD) . Smog and health . Available at : http://www.aqmd.gov/smog/historical /smog_and_health.htm.Accessed March 20,2006.
[8]Tginas OT, Zelikoff JT (1999) Air pollutants moderators of pulmonary host resistance against infection. IN . Air pollution and health. Eds. By Holgate ST, Samet JM, Korean HS, Maynard R, 357-9, Academy Press, San Diego.

[9]Terracini B. Environmental epidemiology : a historical perspective. In : Elliott P, Cuzick J, English D, Stern R, eds. Geographical and Environmental Epidemiology: Methods for Small Area Studies. New York, NY: Oxford University Press: 1992.

[10] The National Academies, Institute of Medicine. Who Will keep the Public Healthy? Educating Public Health Professionals for the $21^{\text {st }}$ Centuary . Washington, DC: The National Academies Press; 2003

[11] US Environmental Protection Agency. The Plain English gide to the Clear Air Act : why should you be concerned about air pollution? Available at:

http://www.epa.gov/oar/oaqps/peg_caa/pegcaa01.html.Accessed March 27, 2005.

\section{RESEARCH PUBLICATIONS:}

[1]Salma Ummul and Kameswara Rao K, 2012, Shift work and Fatigue, Vol.1, Issue 3 ISSN : 2319-2402, pp:17-21, IOSR Journal of Environmnetal Sicence, Toxicology and Food Technology.

[2] Kameswara Rao K and Salma Ummul, 2012, A study on shift work and Health, Vol.2, issue 2, ISSN, 2229-3795, PP 821-826, Asian Journal of Management Research.

[3] Salma Ummul and Kameswara K , 2014, Shiftwork and Blood Pressure, Vol 2, No. 1, ISSN :2349-5820, PP:21-27, International Journal of Basic and Applied Biology (IJBAB)

[4] Salma Ummul and Kameswara Rao K, 2014, Shiftwork and Diabetis, Vol - 2, No. 1, ISSN 2349-5820, PP:44-50, International Journal of Basic and Applied Biology (IJBAB)

[5]Salma Ummul and Kameswara K, Shiftwork and Insomnia , Vol. 2, No 1, ISSN, 2349-5820, PP:65-72, International Journal of Basic and Applied Biology (IJBAB)

[6] Salma Ummul and Kameswara K, Shiftwork and Insomnia, Vol. 2, No. 1, ISSN, 2349-5820, PP:65-72, International Journal of Basic And Applied Biology (IJBAB)

[7] Salma Ummul and Kameswara K, 2014, Shift work and Depression Vol. 4, No. 4, ISSN, 2349-3131, PP:417-422, International Journal of Environmental Research and Development.

[8]Salma Ummul and Kameswara K, 2014, Shiftwork and Depression, Vol. 4, No. 4, ISSN 2249-3131, PP:417-422, International Journal of Environmental Research and Development

[9] Salma Ummul and Kameswara K, 2016, Shiftwork and work load factors, Vol. 3, issue 9, p-ISSN:2394-1545, PP 955-959, Advances in Economics and Business Management (AEBM)

[10] Salma Ummul and Kameswara K, Shift work and Health Consequences, Vol 3, ISSN :2394-5820, PP:227-232, International Journal of Basic and Applied Biology (IJBAB)

[11] Salma Ummul and Kameswara K, 2016, Shift work and Stress, Vol. 3 , Issue 3, P-ISSN - 2394-5820:pp:217-221, International Journal of Basic and Applied Biology

[12] Salma Ummul and Kameswara Rao K, 2016, Shiftworkers and their Academic Profile, Vol 3, issue 3, p-ISSN: 2394-5820:pp:217-221, International Journal of Basic and Applied Biology, (IJBAB)

[13] Salma Ummul and Kameswara K, Shiftwork and Risks in Pregnant Women, Vol . 2, Issue 3, May-June 2017, ISSN :2456-1878

Dr. Ummul Salma, Post Doctoral Fellow (UGC), Andhra University, Visakhapatnam, Andhra Pradesh, India.

Dr. K Kameswara Rao, Professor (Retired), Department of Environmental Sciences, Andhra University, Visakhapatnam , Andhra Pradesh, India. 